\title{
Labor Productivity Inconsistency among Project Sites
}

\author{
Prachi Patel, V. M. Patel
}

\begin{abstract}
As per ministry of statistics and programmeimplementation (2018-2019), construction industry is contributing $7.81 \%$ share in GDP of India. There is an estimated need of around 75 million workers in the building, construction and real estate sector by 2022 (KPMG, 2019).The construction industry has been essential part in the developed and developing countries(Durdyev et al. 2012). The Construction industry in India is expected to grow at 5.6\% during 2016-20(Invest India, 2019). Construction is a labor-intensive industry(Chalise 2015). Construction industry is totally dependent on labor and equipment, so increasing labor productivity by using scientific methods is the need of today's highly growing world. Productivity is usually well-defined as the ratio of outputs to inputs. Laborand equipment productivity are some of the highly influencing factors that affect the physical growth of eachconstruction project. Therefore, to increase the profit margin of construction industry,labor productivity is key factor. This paper presents the bottom-up approach for study of laborproductivity.
\end{abstract}

Key Words: Labor, Productivity, Construction, Factors Affecting, Cost

\section{INTRODUCTION}

India's real estate and construction sector, which is the second largest employer after agriculture, would add another 30 million jobs to the existing 45 million till 2022 (KPMG, 2019). Construction market in India is expected to emerge as the third largest globally (Invest India, 2019). It means that productivity of this sector is highly important for the development of nation as well as the organization associated with this sector. Economic growth and profitability of any organization directly depends upon its productivity. Still there are contractors who do not properly address this strategic issue or understand impact of productivity on the project's profit. To accomplish the revenue estimated from any construction project in general, it is significant to have a good control on the productivity factors like labor, equipment, cash-flow, etc(Jadhav and Wadalkar 2007).

Due to insufficient research in the area of productivity in construction technology, it has been lagged but on other hand manufacturing industry has been benefited from proven production management techniques (Krishna et. al., 2018). To get improvement in the construction productivity sector, it is important to identify the factors that are influencing the productivity.

Revised Manuscript Received on February 05, 2020.

* Correspondence Author

Prachi Patel, Student, Adani Institute of Infrastructure Engineering, Ahmedabad, India.

V. M. Patel, Professor, Adani Institute of Infrastructure Engineering, Ahmedabad, India.

(C) The Authors. Published by Blue Eyes Intelligence Engineering and Sciences Publication (BEIESP). This is an open access article under the CC BY-NC-ND license (http://creativecommons.org/licenses/by-nc-nd/4.0/)
The productivity influence is mainly divided into three main sectors: industry-related, labor-related, and management-related. Some of the factors which influencelaborproductivity includes motivation, experience, skill, and training. Also few factors related to management include planning and direction of project. This study includes labor and management-related factors.

Poor management, inferior working conditions and insufficient quality are some of the major issues faced by the construction industry. To achieve their jobs efficiently, construction labors must be aware with their duties and with the resources, tools, knowledge and machinery they use. Inefficient administration of construction labors will result in low productivity. Therefore, it is significant for contractors and construction managers to be aware with the methods leading to evaluation of efficiency of the construction labors in different activities(Jadhav and Wadalkar 2007). (1) Labor competency; (2) Encouragement programs; (3) Availability of the material and work comfortability; (4) Leadership and management skills; and (5) Supervisory skills are the major factors influencing the productivity.

\section{LITERATURE REVIEW}

There are different definitions given by different researchers for productivity. The mathematical expression of productivity may modify as per requirement of a project. For example, a project developer would be fascinated in estimating its own project productivity by using

$$
\text { Productivity }=\frac{\text { Total Output }}{\text { Total Input }}
$$

Depending upon case conditions the input or output variables may vary. Like when developer is not calculating time factor and interest on investment in the input cost the total input means sum of labour, material and equipment. This is excatly matching with the equation given by Thomas et. al (1990)

$$
\text { Productivity }=\frac{\text { Total Output }}{\text { Labour }+ \text { Material }+ \text { Equiment }}
$$

Productivity is also been calculated in form of

$$
\text { Productivity }=\frac{\text { output }}{\text { Rupees Spent }}
$$

For example, Thomas et al. (1990) mentioned that the Federal Highway Administration was interested in calculating the length of lane constructed vs. dollars spend 
which is very much matching with the above stated equation 2.

In some projects productivity is also been formulated in form of

$$
\text { Productivity }=\frac{\text { output }}{\text { Unit Time }(\text { hour or day or week })}
$$

Many definitions of project labor productivity calculates the different perspectives of the construction industry(Yi and Chan 2014)and some researchers use productivity in the inverse of Eq. (6) as follows(Thomas et al. 1990, Thomas et al. 1992).

$$
\text { Productivity }=\frac{\text { Work Hours }}{\text { Outputs }}
$$

There are two different approaches for study of productivity 1) top-down approach and 2) bottom-up approach. In the first one; we identify the probable factors along with severity and probability and then after on the basis of those data prediction of productivity and its validation whereas in the second approach; we start with actual measurement of productivity on site and then after we try to find out the factors or actions influencing the productivity.

\section{FIELD \& LITERATURE OBSERVATION}

To conduct this study, we have collected construction data of one month from through internship at project site of Ahmedabad. During the internship time we have observed activities like formwork, concreting, block masonry, plastering, etc. The collected data then after processed and compared with other project site data referred from literature.

\section{FACTORS AFFECTING LABOR PRODUCTIVITY}

Productivity is the outcome of several interrelated factors. Various factors affecting labor productivity are reviewed from past studies are discussed below.

Type Of Project / Activity: To accomplish substantial productivity, each member of a crew requires adequate space to perform task without being affected with/by the other crew members. Productivity may decline when more labors are allocated for particular task in a fixed quantity of space because of interference. Moreover, the production may be reduced and interferences rises due to multiple trades allocated to work in the identical area (Jadhav and Wadalkar 2007). Mismanagement on construction sites increases interferences amongst numerous labors. For example, a reinforcement work crew has to wait if the formwork is incomplete. The way of working and technology adopted for construction also impact labor productivity. In our study (Figure 1) we have noticed that there is direct relationship between labor productivity and hardship involved in the work. Also Table 1 shows that for the same activity there is vast change in productivity at different project site which reveal us about the influence of project conditions on productivity of activities.

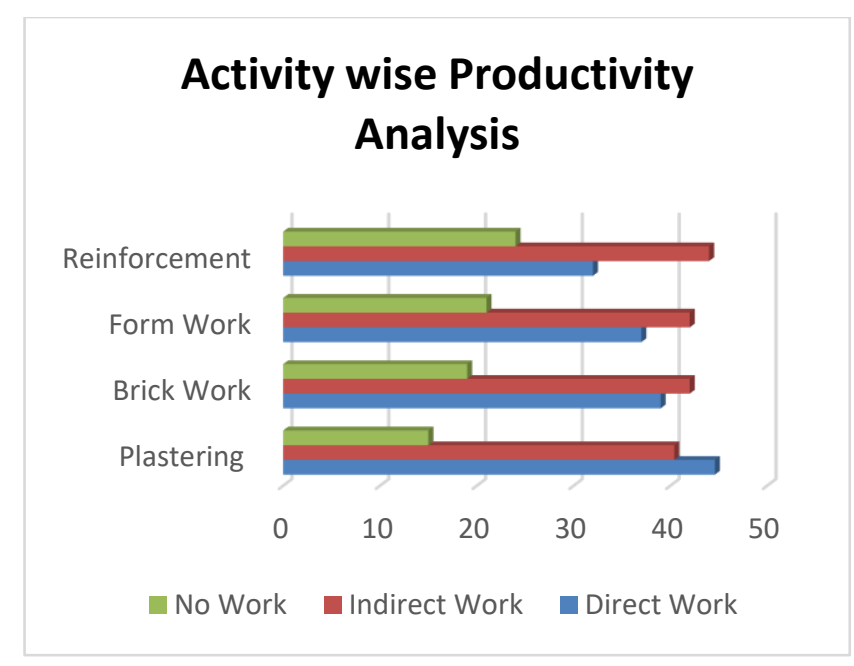

Figure 1: Activity wise Productivity Analysis

Occupational Safety\& Site Conditions: Accidents have high impacts on labor productivity(Kasap 2011). Various accident types occur at the site, such as an accident triggering death and resulting in a total work stoppage for couple of days. Even insufficient lighting shows reduced productivity because sufficient lighting is essential to work efficiently and because insufficient lighting may increase possibility of accidents and reduce productivity(Jiang et al. 2015). It has been also noticed that in the initial days of project / activity, productivity is little lower and after getting the site / activity conditions familiar, productivity increases. From T-test of productivity and floor level, we have received the value of $\mathrm{P}=3.46953931932356 \mathrm{E}^{-12}$ and value of $\mathrm{t}$-critical $=1.76131013577489$. it shows that the results are significant.

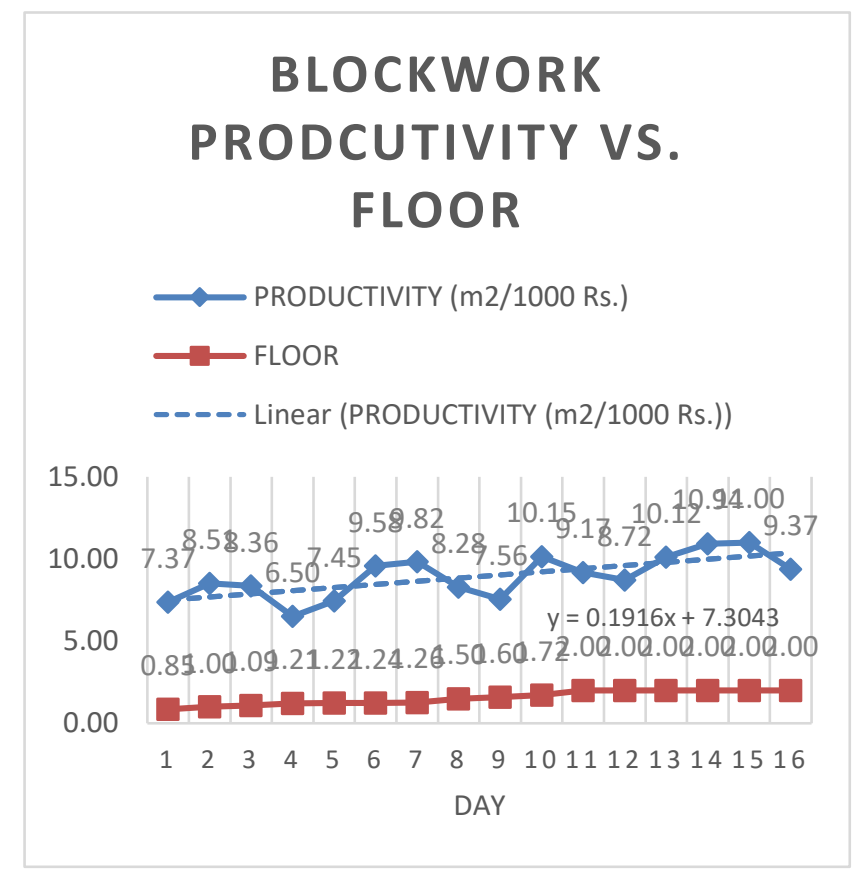

Figure 2: Productivity of block work at Ahmedabad project site 
Quality of Physical Resources: Factors responsible for low productivity are inefficient equipment and poor quality of the raw material. Also, the incompetent equipment has low productivity rate(Gerges 2015). Moreover, the productivity is reduced because of the old equipment subjected to a great number of failures, and it takes a long time for the laborers to complete the work. Poor-quality material used for work is the added feature because poor materials usually lead to unsatisfactory work and can be rejected by supervisors, thus reducing the productivity. As per the report (Teicholz, 2004), labor productivity index from 1964 through 2003 for US construction industry has decline nature while all non-farm industries has incline nature. This observation is because of development of hightech instruments / equipment in non-farm industries compare to construction industry. It has been also noticed by researchers that with advancement in quality of equipment in highway construction productivity of laborers is increasing in last decade(Sveikauskas et al. 2016). In order to overcome such inefficiency, innovative and more creative approaches need to be implemented within the construction industry(Teicholz 2004).

Working Time: In construction projects, loss of productivity occurs frequently. It has been discovered from the past study that productivity decreases with working overtime(Gopal and Murali 2015). Some of the most common stated reasons are fatigue; improved absenteeism; reduced morale; lack of supervision; poor workmanship, resultant in higher rework; increased accidents. It has been observed that working overtime initially has outcome in increased output, but ongoing overtime leads to bigger costs and reduced productivity(Enshassi et al. 2007). Time used by a construction labors on useful activities averages about $30 \%$ of the overall time available. An employee in the field only works efficiently for 3.5 hours of his 8-hour shift and spends $20 \%$ of his time on direct value-adding doings(Jadhav and Wadalkar 2007).

Manpower Training \& Grouping: Literature appearances that absence of labor experience is the issue which negatively affects labor productivity and demonstrates that, to attain good productivity, labor plays a significant role(Mahamid 2013). Contractors should employ expert labors to get more productivity. If expert labor is unavailable and a contractor is essential to complete precise task with less-skilled labor, it is possible that productivity will be affected and to increase the productivity prior training may help the contractor. Our study (figure 2) shows that for the same task under the same environment productivity of each labor is different one depends on his experience and training. The lack of any crew member may influence the crew's production rate because workers will, typically, be incapable to achieve the same production rate with fewer resources and with different crew members. Misunderstanding among laborers generates disagreements about responsibilities and the work bounds of every laborer, which leads to a lot of work errors and decreases labor productivity. It has been also noticed

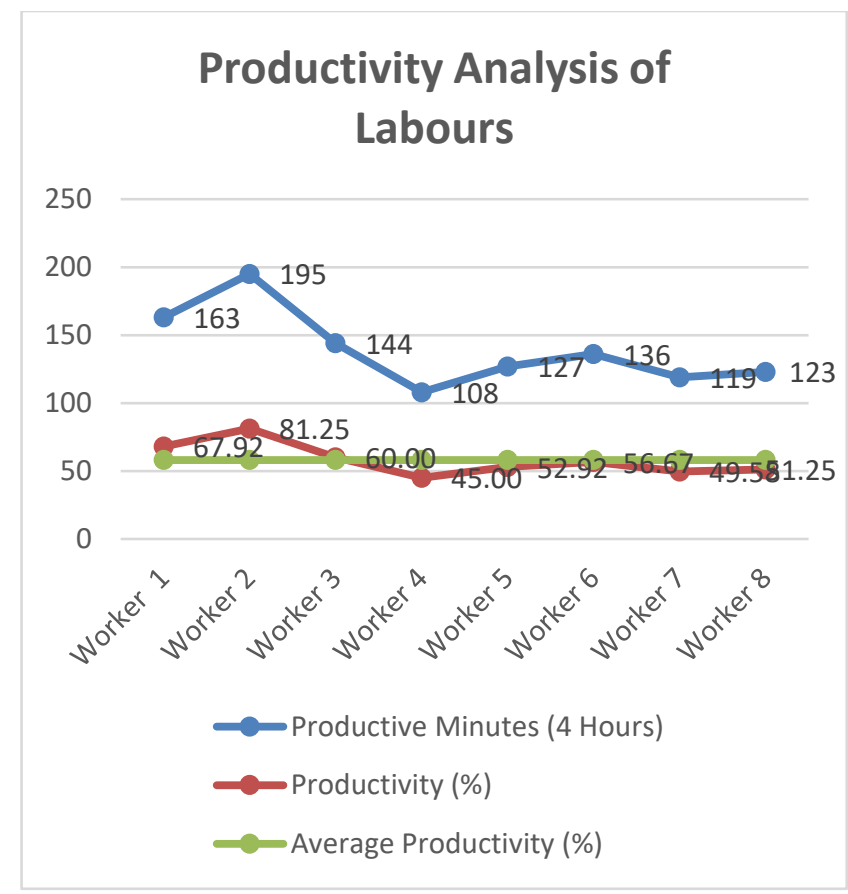

Figure 3: Productivity analysis of labors at Ahmedabad project site

\section{Management systems:}

Project supervisors can adjust schedules, and modify working methods.Rojas and Aramvareekul (2003)stated that management skills, scheduling, material and equipment management, and quality control are the most influencing factors on labor productivity.Even due to the addition of latest technology and trained manpower are made available in many organization still the productivity rate is low(Rojas and Aramvareekul 2003). The shortcoming in project strategy generates increased waiting time of labors and equipment, labor workload, or rework items(Gundecha 2013).

\section{RESULTS \& ANALYSIS}

\section{Concrete Bucket Time Analysis}

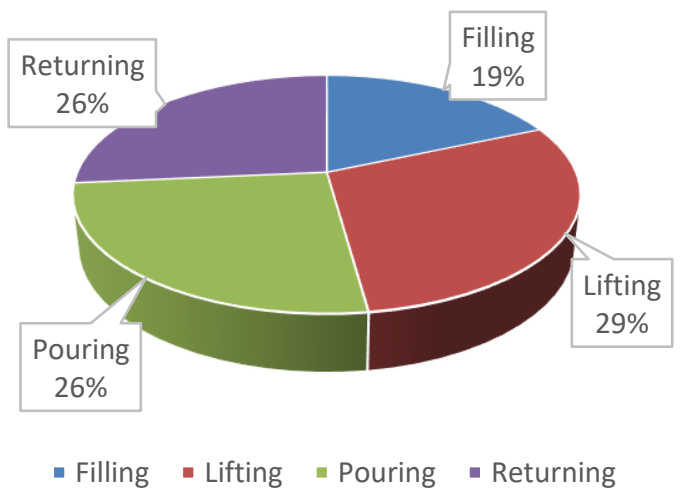

Figure 4: Concrete bucket productivity analysis 


\section{Labor Productivity Inconsistency among Project Sites}

Figure 4 reveals that utilization of bucket is only $26 \%$ for the pouring purpose the rest $74 \%$ time is utilized for other associated task along with considerable waiting time.

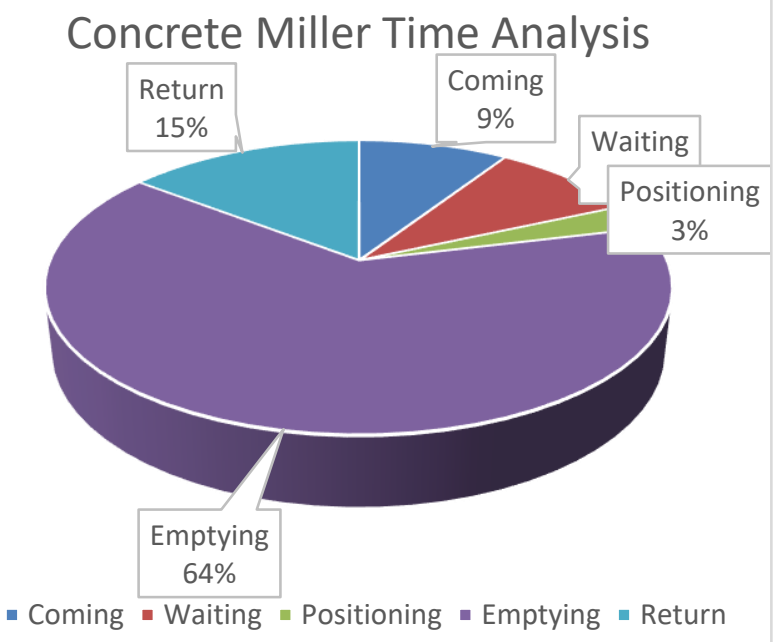

Figure 5 states that concrete miller is utilizing its 64\% time for emptying and only $9 \%$ time is waiting time. It shows that on Ahmedabad project site, they have managed resources well to get best output.

Figure 5: Concrete miller productivity analysis

Table 1: Productivity of activities at different project sites

\begin{tabular}{|c|c|c|c|c|}
\hline Sr. No. & Reference & Activity & Average Productivity & Unit \\
\hline 1 & Enshassi et. al., 2007 & Flyer Table Productivity & 0.15 & Table / Hour \\
\hline 2 & Ranasinghe et. al., 2016 & Deck Form Work & 33.01 & $\mathrm{~m}^{3} / \mathrm{man}$ day \\
\hline 3 & kumar et. al., 2014 & Reinforcement work & 53.8 & kg/man day \\
\hline 4 & kumar et. al., 2014 & Brickwork & 0.68 & $\mathrm{~m}^{2} / \mathrm{man}$ day \\
\hline 5 & Enshassi et. al., 2007 & Masonry work & 16.11 & $\mathrm{~m}^{2} / \mathrm{man}$ day \\
\hline 6 & Enshassi et. al., 2007 & Masonry work & 15.31 & $\mathrm{~m}^{2} / \mathrm{man}$ day \\
\hline 7 & Project Site, Ahmedabad, 2019 & Block work & 3.71 & $\mathrm{~m}^{2} / \mathrm{man}$ day \\
\hline 8 & kumar et. al., 2014 & Plastering & 12 & $\mathrm{~m}^{2} / \mathrm{man}$ day \\
\hline 9 & Project Site, Ahmedabad, 2019 & Plastering & 10.74 & $\mathrm{~m}^{2} / \mathrm{man}$ day \\
\hline 10 & Thomas \& Sudhakumar, 2013 & Scaffolding Work & 0.42 & $\mathrm{~m}^{2} / \mathrm{man}$ day \\
\hline 11 & kumar et. al., 2014 & Formwork & 6.08 & $\mathrm{~m}^{2} / \mathrm{man}$ day \\
\hline 12 & Zohar Herbsman a \& Ralph Ellis, 2013 & Formwork & 6.15 & $\mathrm{~m}^{2} / \mathrm{man}$ day \\
\hline 13 & Zohar Herbsman a \& Ralph Ellis, 2013 & Formwork & 18.28 & $\mathrm{~m}^{2} / \mathrm{man}$ day \\
\hline
\end{tabular}

\section{CONCLUSION}

- In current world of competition there is a need to improve labor as well as equipment productivity to get competitive profit. Sensors and latest technology can help us to improve the productivity.

- Productivity in construction industry is varying from place to place and project to project. Compare to manufacturing industry, in construction industry productivity is considerably low because of changing in environment, depending on team mates, project site conditions, etc.
- It is observed that labor productivity is increasing when labor is familiar with the work situation working space.

- Productivity is lower in case of hard activity like lifting or transporting heavy material from one place to another place or working at heights. So suitable equipment and proper safety measures may increase the productivity. 


\section{REFERENCES}

1. Chalise, E. B. (2015). "Labor-Intensive Construction Method to Foster Employment Opportunities in Developing Countries, Prospects from South Asian Economy."

2. Durdyev, S., et al. (2012). "Factors causing cost overruns in construction of residential projects: case study of Turkey." International Journal of Science and Management1(1): 3-12.

3. Enshassi, A., et al. (2007). "Factors affecting labour productivity in building projects in the Gaza Strip." Journal of civil engineering and management13(4): 245-254.

4. Gerges, M. (2015). "Investigation into the labour factors affecting project performance within the Egyptian construction industry." Coventry University: 30-34.

5. Gopal, T. S. R. and K. Murali (2015). "A critical review on factors influencing labour productivity in construction." IOSR Journal of Mechanical and Civil Engineering12(5): 47-51.

6. Gundecha, M. M. (2013). "Study of factors affecting labor productivity at a building construction project in the usa: web survey."

7. Jadhav, S. K. and S. Wadalkar (2007). "Study and analysis for labour productivity factor for construction activities in commercial projects: a survey." International Journal of Innovative Research in Science, Engineering and Technology6(1): 1410-1417.

8. Jiang, Z., et al. (2015). "Understanding the causation of construction workers' unsafe behaviors based on system dynamics modeling." Journal of management in engineering31(6): 04014099.

9. Kasap, Y. (2011). "The effect of work accidents on the efficiency of production in the coal sector." south African journal of science107(5-6): 77-85.

10. Mahamid, I. (2013). "Contractors perspective toward factors affecting labor productivity in building construction." Engineering, Construction and Architectural Management.

11. Rojas, E. M. and P. Aramvareekul (2003). "Labor productivity drivers and opportunities in the construction industry." Journal of management in engineering19(2): 78-82.

12. Sveikauskas, L., et al. (2016). "Productivity growth in construction." Journal of construction engineering and management142(10): 04016045.

13. Teicholz, P. (2004). "Labor productivity declines in the construction industry: causes and remedies." AECbytes Viewpoint4(14): 2004.

14. Thomas, H. R., et al. (1990). "Modeling construction labor productivity." Journal of construction engineering and management116(4): 705-726.

15. Thomas, H. R., et al. (1992). "Comparison of labor productivity." Journal of construction engineering and management118(4): 635650.

16. Yi, W. and A. P. Chan (2014). "Critical review of labor productivity research in construction journals." Journal of management in engineering30(2): 214-225.

17. KPMG (2019). "Disruptions in the Real Estate in India." 